\title{
Meckel diverticulum with ectopic pancreatic tissue in a 12-year-old boy with intestinal invagination. Case report and review of the literature
}

\author{
Divertículo de Meckel con tejido pancreático ectópico en un niño de 12 años con \\ invaginación intestinal. Reporte de caso y revisión de la literatura
}

Sonia Guzmán-Martínez" *, Alfonso Galván-Montaño", Sonia Lara-Escalera², $M^{a}$ del Rocío Estrada-Hernández ${ }^{3}$, Alejandro García-Peña ${ }^{4}$, Erika G. Castañeda-Ángeles ${ }^{3}$, Paulina Rojas-Muñoz ${ }^{4}$ and Silvia García-Moreno ${ }^{5}$

${ }^{1}$ Pediatric Surgery, Department of Pediatrics; ${ }^{2}$ Teaching Division; ${ }^{3}$ Anatomic Pathology Division; ${ }^{4}$ Department of Diagnostic and Therapeutic Imaging; ${ }^{5}$ Clinical Research Division. Hospital General Dr. Manuel Gea González, Mexico City, Mexico

\begin{abstract}
\end{abstract}

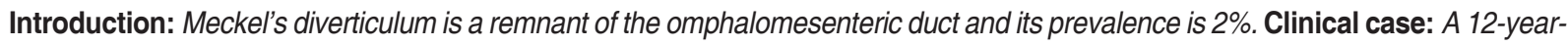
old male with abdominal pain, accompanied by muco-sanguineous evacuations and hematemesis, with right lower quadrant mass. In the laparotomy, invasion was found; intussusception reduction and resection of the Meckel's diverticulum was performed. Conclusion: The association of Meckel's diverticulum with heterotopic pancreatic tissue in children is rare, its main manifestation is intussusception and ultrasound is an option for diagnosis.

KEY WORDS: Meckel diverticulum. Ectopic pancreatic tissue. Intussusception.

\section{Resumen}

Introducción: El divertículo de Meckel es un remanente del conducto onfalomesentérico y su prevalencia es deloz\%. Caso clínico: Niño de 12 años con dolor abdominal, acompañado de evacuaciones mucosanguinolentas y hematemesis, con masa en cuadrante inferior derecho. En la laparotomía quirúrgica se encontró invaginación, y se realizó desinvaginación y resección del divertículo de Meckel. Conclusión: La asociación de divertículo de Meckel con tejido pancreático heterotópico en niños es poco frecuente. Clínicamente, su principal manifestación es la invaginación intestinal en la literatura revisada, y el ultrasonido constituye el mejor estudio para el diagnóstico de invaginación intestinal, no así para el divertículo de Meckel o el tejido pancreático heterotópico, en los que la tomografía sería una opción.

PALABRAS CLAVE: Divertículo de Meckel. Tejido pancreático ectópico. Invaginación intestinal.

\section{Correspondence:}

*Sonia Guzmán-Martínez

Calzada de Tlalpan,

Col. Sección XVI, Del. Tlalpan

C.P. 14080 , Mexico City, Mexico

E-mail: urologiapediatrica2000@gmail.com
Date of reception: 27-02-2018

Date of acceptance: 15-05-2018

DOI: $10.24875 / C I R U E . M 18000068$
Cir Cir. 2018;86:399-403

Contents available at PubMed www.cirugiaycirujanos.com 


\section{Introduction}

Meckel's diverticulum is a remnant of the omphalomesenteric duct, located on the antimesenteric border of the ileum, at $40-60 \mathrm{~cm}$ from the ileocecal valve, and it is characterized for containing all the layers normally found in the ileum ${ }^{1-3}$. The prevalence of Meckel's diverticulum is approximately $2 \%$ in the general population; of total cases, $76 \%$ are in adults and $24 \%$ in pediatric patients ${ }^{2,3}$.

In $62 \%$ of cases heterotopic gastric mucosa can be found, in $6 \%$, pancreatic tissue, in $5 \%$, gastric and pancreatic mucosa, in $2 \%$, jejunum mucosa and in $2 \%$ Brunner's tissue ${ }^{4}$. Clinical presentation can include intestinal bleeding, pain, intestinal occlusion or intussusception $^{5}$. It can be diagnosed with technetium-99 scintigraphy when there is ectopic gastric mucosa, but computerized tomography is the method that has been shown to be the most specific, showing a tubular structure filled with fluid or intestinal intussusception images ${ }^{6}$.

The purpose of this paper is to present a case of Meckel's diverticulum with heterotopic pancreatic tissue in a 12-year-old boy with intestinal intussusception, as well as to perform a review of the literature, since this is a rare pathology and we did not find cases reported in the national literature.

\section{Clinical case}

Twelve-year-old boy with a history of laparoscopic appendectomy at 10 years of age. He attended the emergency department with an 8-hour history of abdominal pain, located at the mesogastrium with 10/10 intensity, accompanied by muco-sanguineous stools in seven occasions, which subsequently were melenic. There were episodes of vomiting on eight occasions, with gastro-alimentary content and then with blood. On physical examination, blood pressure of $129 / 48 \mathrm{mmHg}$, mean blood pressure of $73 \mathrm{mmHg}$, heart rate at 100 beats per minute, respiratory rate of 28 breaths per minute, temperature of $36{ }^{\circ} \mathrm{C}, 86 \%$ saturation and weight of $51 \mathrm{~kg}$ were observed. Dehydrated, conscious, oriented, pale oral mucosa, lung fields with air adequately flowing in and out. Precordium with heart sounds increased in intensity, without murmurs. Soft, depressible abdomen. With a diagnosis of digestive tract bleeding of etiology to be determined, management with omeprazole, acetaminophen and ondansetron was administered for 48 hours, with no improvement. Laboratory tests reported hemoglobin $15.00 \mathrm{~g} / \mathrm{dL}$, platelets 193,000, white blood cells 10,600 x $10^{3} \mu \mathrm{L}$, neutrophils $89.70 \%$, lymphocytes $9.10 \%$, monocytes $1 \%$, basophils $0.20 \%$, creatinine 0.82 , glucose $128 \mathrm{mg} / \mathrm{dL}$, sodium $139 \mathrm{mEq} / \mathrm{L}$, potassium $=4.1$ $\mathrm{mEq} / \mathrm{L}$, calcium $9.40 \mathrm{mg} / \mathrm{dL}$ and C-reactive protein (CRP) $0.793 \mathrm{mg} / \mathrm{dL}$. A pan-endoscopy did not reveal active bleeding in the stomach or esophagus. Since on abdominal palpation a mass was felt in the lower right quadrant, an ultrasound was carried out, which reported a fluid-free image with a "bull's eye" appēarance, suggestive of invagination. The intussusception head was displayed at the hepatic angle, with a pediculate, rounded image dependent on a handle of the small intestine being identified at the center (Fig.드).

With the diagnosis of intestinal intussusception with more than 48 hours of evolution, and considering the patient age, performing a surgical examination was decided, where double invagination was found: ileoileal and ileocolic intussusception (Fig. 2), with the first ileoileal segment harboring a Meckel diverticulum inverted on its axis and this segment doubly invaginated to the ascending colon. Desinvagination by taxis was carried out, together with intestinal resection of the Meckel diverticulum located at $40 \mathrm{~cm}$ of the ileocecal valve (Fig. 3), with $5 \mathrm{~cm}$ of intestine at each sideand end-to-end anastomosis. Postoperative evolution was favorable, and the patient was discharged without complications, and at the moment of the report he was in good health conditions.

On histopathological examination, macroscopically, the intussuscepted Meckel diverticulum was obseived with its three layers and, at the center, solid-looking, light yellow tissue, reminiscent of pancreatic tissue (Fig. 4). On histological section, pancreatic acini and slightly dilated ducts could be appreciated; there Were no Langerhans islets (Fig. 5).

\section{Discussion}

Heterotopic pancreas is defined as pancreatic tissue without a true anatomical or vascular connection with the pancreas, and was first reported by JeanSchultz in $1729^{7,8}$. Other terms used are ectopic pancreas, accessory pancreas and aberrant pancreas. In 1859, Zenker reported the first case of ectopic pancreas in a Meckel diverticulum ${ }^{9}$.

Heterotopic pancreas origin is still unclear, bat it is believed to arise embryonically during rotation of the foregut and fusion of the dorsal and ventral pancreatic tissue, where some tissue separates from the 


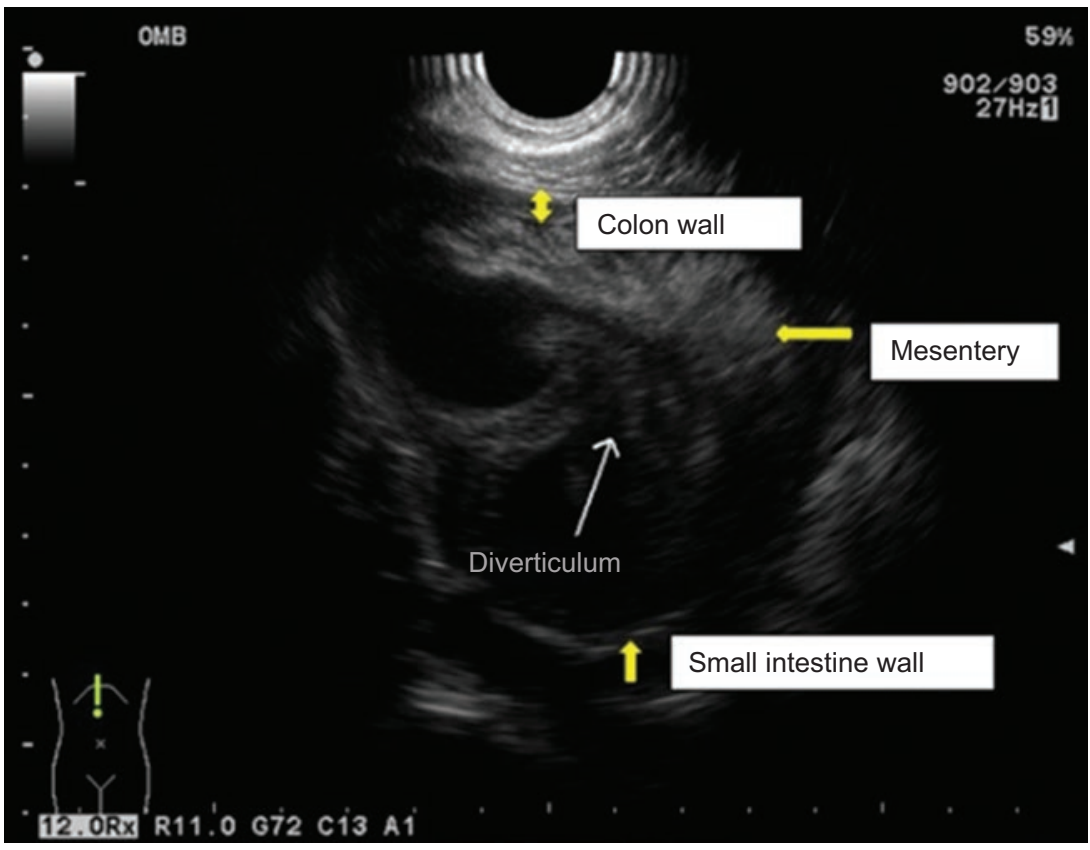

Figure 1. Abdominal ultrasound, where the intussusception head is visualized, with a pediculate, rounded image, dependent on a small bowel loop, is centrally identified in the internal lateral face.

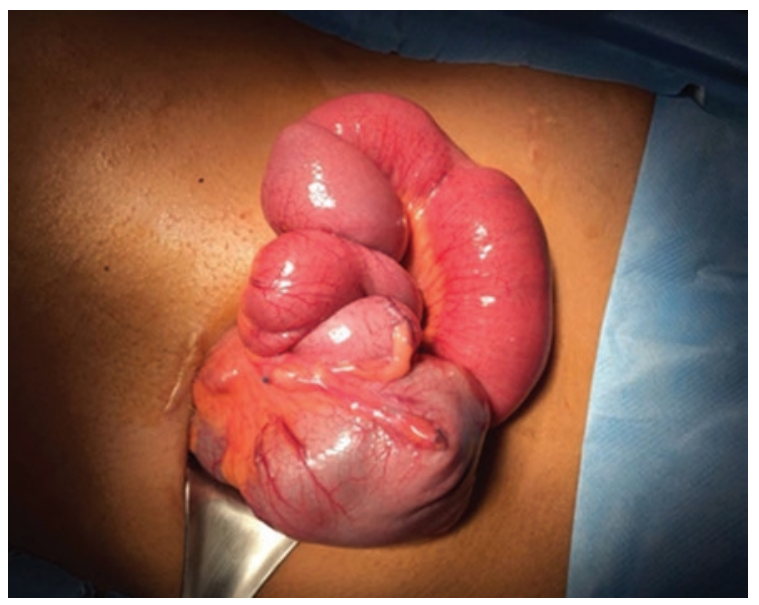

Figure 2. Double intestinal intussusception: ileoileal and ileocolic.

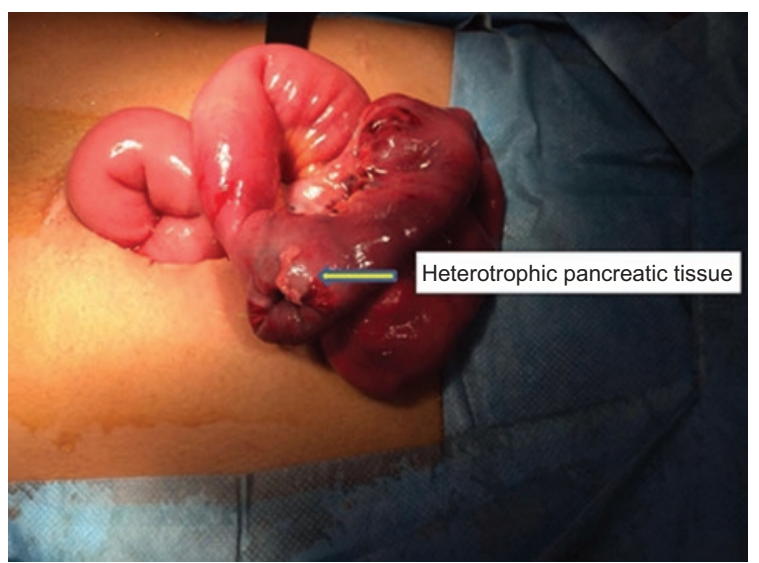

Figure 3. Meckel's diverticulum with heterotopic pancreatic tissue. pancreas and develops in any portion of the intestine. Another best known theory is based on the pancreatic metaplasia of endodermal tissue 8,9 . Bue to the proximity of embryonic pancreatic primo dial buds and the foregut during development, $70-90 \%$ of ectopic pancreas occurs in the upper portion of the digestive tract $^{10}$.

Most patients with Meckel's diverticulum are asymptomatic and the diagnosis is usually made by scintigraphy with technetium-99, tomography, endoscopy or during surgical examination motivated by other diseases. In children, most cases are detected due of the presence of intestinal intussusception. Heterotopic pancreatic tissue visualization is difficult, and we-only found one report where heterotopic pancreatic tissue could be identified in a Meckel's diverticulum as a homogeneous, hypoechoic and well-defined mass on ultrasound ${ }^{11}$.

According to Heinrich's criteria, heterotopic panereas is classified as type 1 if it contains cells of exocrine glands, excretory ducts and islets of Langerhāns, type 2 if it contains excretory glands and excretory ducts, and as type 3 if there are only excretory ducts. The most common is type 2 , followed by type 1 , while type 3 is uncommon ${ }^{12-14}$. Our case corresponded to type 2.

In our literature review, we were able to document 10 cases reported in children from 23 days to 15 years of age, $60 \%$ in children older than 2 years and $70 \%$ 
Table 1. Documented cases of children from 23 days to 15 years of age with Meckel's diverticulum and heterotopic pancreatic tissue

\begin{tabular}{|c|c|c|c|}
\hline Author, year & Age & Gender & Presentation \\
\hline Guanà et al. ${ }^{6}, 2014$ & 7 years & Female & Intussuscepti \\
\hline Baysoy et al. ${ }^{15}, 2010$ & 5 years & Male & Intussuscepti \\
\hline Xiao et al. ${ }^{5}, 2009$ & 12 years & Male & Intussuscepti \\
\hline Huml et al. ${ }^{16}, 2009$ & 1 month & Male & Pain, nausea \\
\hline Ogata et al. ${ }^{17}, 2007$ & $\begin{array}{c}1 \text { year } \\
4 \text { years } \\
10 \text { years } \\
23 \text { days }\end{array}$ & $\begin{array}{l}\text { Female } \\
\text { Female } \\
\text { Male } \\
\text { Male }\end{array}$ & $\begin{array}{l}\text { Meckel's dive } \\
\text { Intussuscepti } \\
\text { Meckel's dive } \\
\text { Meckel's dive }\end{array}$ \\
\hline Orri et al. ${ }^{18}, 2006$ & 7 months & Male & Intussuscepti \\
\hline Clog et al. ${ }^{20}, 1908$ & 12 years & Male & Abdominal di \\
\hline Current case & 12 years & Male & Intussuscepti \\
\hline
\end{tabular}

Figure 4. On the antimesenteric border, intussuscepted Meckel's diverticulum with its three layers is observed, and on the center, solid-looking, light yellow tissue, reminiscent of pancreatic tissue.

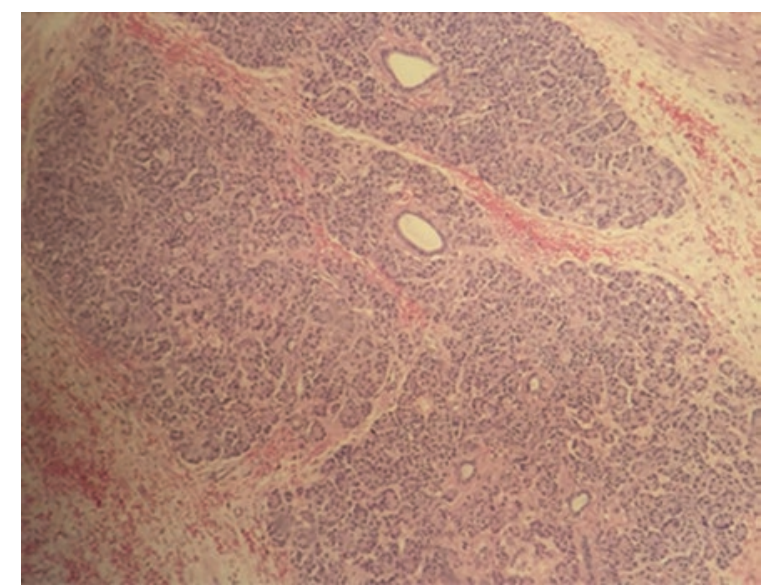

Figure 5. Histological section with pancreatic acini and slightly dilated ducts. There are no islets of Langerhans.

in males (Table 1). Around $50 \%$ had a presentation with intussusception, $30 \%$ with Meckel's diverticulum and, in two cases, exploratory laparotomy was performed without an accurate diagnosis being established, and was based only on the presence of abdominal pain, vomiting or abdominal distension. In five cases, the type was reported according to Hèinrich's histological classification, with types 1 añ 2 being the most common ${ }^{5,6,15-20}$.

We consider that heterotopic pancreatic tissue favors the presence of intestinal intussusception, and the literature also refers that if a patient devetops acute pancreatitis in the "mother" organ, inflammation will also affect heterotopic foci, causing abdominal pain with elevation of pancreatic enzyme blood levels, which did not occur in our patient ${ }^{14}$.

\section{Conclusions}

Association of Meckel's diverticulum with heterotopic pancreatic tissue in children is rare. Clinicallly, its main manifestation is intestinal intussusception in the reviewed literature. Ultrasound is the best study for diagnosis of intestinal intussusception, cbut not so for Meckel's diverticulum and heterotopic pancreatic tissue, where tomography would be option.

\section{References}

1. Levy AD, Hobbs CM. Meckel diverticulum: radiologic features with-pathologic correlation. Radiographics. 2004;24:565-87.

2. Robustelli U, Manguso F, Armellino MF, Mannelli MP, Massa MR, Forner AL, et al. Acute symptomatic Meckel diverticulum management. Our experience on seven consecutive cases. Ann Ital Chir. 2014;85:129-35.

3. Elsayes KM, Menias CO, Harvin HJ, Francis IR. Imaging manifestations of Meckel's diverticulum. AJR Am J Roentgenol. 2007;189:81-8.

4. Burjonrappa S, Khaing P. Meckel's diverticulum and ectopic epithelium: evaluation of a complex relationship. J Indian Assoc Pediatr Surg. 2014;19:85-9. 
5. Xiao WD, Chen W, Yang H. Heterotopic pancreas within Meckel's diverticulum with obscure then massive gastrointestinal bleeding in a 12-yearold child: case report and review of the literature. J Int Med Res. 2009;37:967-72.

6. Guanà R, Bucci V, Carbonaro G, Cerrina A, Ferrero L, Teruzzi E, et al. Heterotopic pancreas in Meckel's diverticulum in a 7-year-old child with intussusception and recurrent gastrointestinal bleeding: case report and literature review focusing on diagnostic controversies. Afr J Paediatr Surg. 2014;11:354-8.

7. Pearson S. Aberrant pancreas. Review of the literature and report of three cases, one of which produced common and pancreatic duct obstruction. AMA Arch Surg. 1951;63:168-96.

8. Tanaka K, Tsunoda T, Eto T, Yamada M, Matsuo S, Izawa K. Diagnosis and management of heterotopic pancreas. Int Surg. 1993;78:32-5.

9. Okamoto H, Fujishima F, Ishida K, Tsuchida K, Shimizu T, Goto H, et al. Intraductal papillary mucinous neoplasm originating from a jejunal heterotopic pancreas: report of a case. Surg Today. 2014;44 349-53.

10. Bromberg SH, Neto CC, Fernando A, Borger A, Franco MIF, Franca LCM, et al. Pancreatic heterotopias: clinicopathological analysis of 18 patients. Rev Col Bras Cir. 2010;37:413-9.

11. Monedero MD, Ripollés T, Nicolau MJ, Martínez-Pérez MJ. Pancreatic pseudotumor in Meckel diverticulum. Abdom Imaging. 2006;631:688-90.
12. Gunjača I, Mlinac-Lucijanic M, Pavlovic A, Gunjača M. Inflammation of ectopic pancreatic tissue as unusual case of duodenal perforation- a case report. Antropol. 2010;3:1119-22.

13. Heinrich H. Ein Beitrag Zur Histologie des Sogenakzessorischen Pancreas. Virchows. Arch Path Physiol. 1909;198:392-401.

14. Zarand A, Bajtai A, Baranyai Z, Dede K, Jakab F. Inflammation of ectopic pancreatic tissue in a Meckel's diverticulum causing acute abdominal symptoms: a case report and review of the literature. Int J Surg Pathol. 2011;19:359-63.

15. Baysoy G, Balamtekin N, Uslu N, Karavelioğlu A, Talim B, Özen H. Double heterotopic pancreas and Meckel's diverticulum in a chifd: do they have common origin? Turk J Pediatr. 2010;52:336-8.

16. Huml M, Sýkora J, Kobr J, Pizingerová K, Šebor J, Skála V, et al. Ḧeterotopickýpankreas, ileokolickáinvaginace v kojeneckémvěku" Pediatr pro Praxi. 2009;10:191-2.

17. Ogata H, Oshio $T$, Ishibashi $H$, Takano S, Yagi M. Heterotopic pañereas in children: review of the literature and report of 12 cases. Pediatrsurg Int. 2008;24:271-5.

18. Orri TO, Ingibjorg G, Ronald M. Diagnosis and treatment of gastrie heterotopic pancreas. World J Surg. 2006;30:1682-9.

19. Ormarsson OT, Gudmundsdottir I, Mårvik R. Diagnosis and treatment of gastric heterotopic pancreas. World J Surg. 2006;30:1682-9.

20. Clog H. Acute Intestinal Obstruction. Lancet. 1908;1:639. 